\title{
Growth and chlorophyll in noni seedlings irrigated with saline water in substrate with vermicompost
}

\author{
Daiane G. dos Santos ${ }^{1}$, Belísia L. M. T. Diniz ${ }^{2}$, Manoel A. Diniz Neto ${ }^{2}$, João H. C. S. Silva ${ }^{3}$, \\ William N. de Oliveira Filho ${ }^{4}$ \& Roberto M. Ferreira Filho ${ }^{4}$
}

\footnotetext{
${ }^{1}$ Universidade Federal da Paraíba/Centro de Ciências Agrárias/Programa de Pós-Graduação em Zootecnia. Areia, PB, Brasil. E-mail: daianeagro@outlook.com (Corresponding author) - ORCID: 0000-0001-9629-0441

${ }^{2}$ Universidade Federal da Paraíba/Departamento de Agricultura. Bananeiras, PB, Brasil. E-mail: belisia.diniz@gmail.com - ORCID: 0000-0002-7580-2433; diniznetto@gmail.com - ORCID: 0000-0002-3190-8682

${ }^{3}$ Universidade Federal da Paraíba/Centro de Ciências Humanas, Sociais e Agrárias/Programa de Pós-Graduação em Ciências Agrárias (Agroecologia). Bananeiras, PB, Brasil. E-mail: joaohenriqueconst@gmail.com - ORCID: 0000-0001-6218-5096

${ }^{4}$ Universidade Federal da Paraíba/Centro de Ciências Agrárias/Programa de Pós-Graduação em Ciência do Solo. Areia, PB, Brasil. E-mail: wnovaes39@gmail.com - ORCID: 0000-0003-4035-8245; robertomonteiroff@yahoo.com - ORCID: 0000-0002-2905-258X
}

\begin{abstract}
Irrigation is a limiting factor for the development of crops, and all water sources contain salts, which can accumulate in the soil and in the plant, compromising its development. The use of vermicompost is one of the alternatives to mitigate the negative effects of salts on plants. This organic compost is a soil conditioner and a nutrient source for plants. Thus, this study aimed to evaluate the growth and chorophyll of noni (Morinda citrifolia L.) in response to the salinity of irrigation water in substrates with and without vermicompost. A completely randomized design in a $4 \times 3$ factorial scheme was used, corresponding to four levels of electrical conductivity of the irrigation water $\left(0.5,1.5,3.0\right.$ and $\left.4.5 \mathrm{dS} \mathrm{m}^{-1}\right)$, in three soil substrates (without humus, with 33.33 and $66.66 \%$ of humus). Three months after germination, the following variables were evaluated: plant height; stem diameter; number of leaves; chlorophyll index ( $a, b$ and total) in the leaves; and fresh and dry matter of shoots and roots. The increase of salinity in irrigation water negatively influences growth in height, stem diameter, biomass production and chlorophyll a and total indexes, but with lower intensity in substrates with humus, that improves the fertility of the substrate and favors the growth of noni plants, regardless of the salinity of the irrigation water; however, its beneficial effect decreases with the intensification of electrical conductivity of irrigation water.
\end{abstract}

Key words: Morinda citrifolia, salt stress, organic input

\section{Crescimento e clorofila em mudas de noni irrigadas com água salina em substrato com vermicomposto}

RESUMO: A irrigação é um fator limitante para o desenvolvimento das culturas, e todas as fontes de água contem sais, podendo acumular-se no solo e na planta, comprometendo seu desenvolvimento. Dentre algumas alternativas para atenuar os efeitos negativos dos sais nos vegetais está a utilização de vermicomposto, sendo este um adubo orgânico condicionador do solo e fonte de nutrientes para as plantas. Dessa forma, o estudo teve como objetivo avaliar o crescimento e o índice de clorofila do noni à salinidade da água de irrigação em substrato sem e com proporções de vermicomposto. Foi utilizado o delineamento inteiramente casualizado, com quatro repetições utilizando o esquema fatorial $4 \times 3$, correspondente a quatro níveis de condutividade

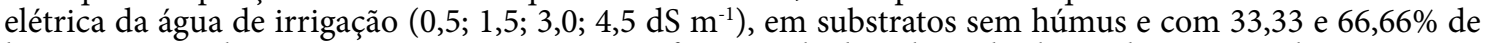
húmus com o solo. Três meses após a germinação foram avaliados: altura de planta; diâmetro caulinar; número de folhas; índices de clorofila (a, b e total) das folhas; e matéria fresca e seca da parte aérea e radicular das plantas. O aumento da salinidade na água de irrigação influência negativamente no crescimento em altura, diâmetro caulinar, produção de biomassa e índices de clorofila a e total, mas com menor intensidade nos substratos com húmus, que melhora a fertilidade do substrato e favorece o crescimento das plantas de noni, independentemente da salinidade da água de irrigação; no entanto, seu efeito benéfico diminui com o aumento da condutividade elétrica da água de irrigação.

Palavras-chave: Morinda citrifolia, estresse salino, insumo orgânico 


\section{INTRODUCTION}

Noni (Morinda citrifolia L.) is a fruit crop belonging to the family Rubiaceae, originally from Micronesia, according to Razafimandimbison et al. (2010). It was recently introduced in Brazil, where its planting is focused on commercial cultivation (Silva et al., 2014). This species has aroused the interest of consumers due to its medicinal properties.

This plant is highly adaptable to tropical countries, standing out for its ability to develop in soil, climate and extreme environment conditions (Basar et al., 2010; Souto et al., 2015a). It is considered a salinity-tolerant crop for surviving in areas flooded by tsunamis and saline environments, without presenting symptoms of foliar toxicity (Silva \& Cavalcante, 2014). Souto et al. (2016) observed that noni plants in soil without salt leaching did not survive when irrigated with water salinity of $5.28 \mathrm{dS} \mathrm{m}^{-1}$.

Irrigation is a fundamental factor for the development of crops, especially in semi-arid and arid regions, since water sources in these regions contain salts, which can accumulate in the soil and in the plant. The accumulation of salts can cause alterations of the physical and chemical attributes of the soil and, by the action of the specific ions, on the germination, growth, production and plant nutrition (Amorim et al., 2010; Cavalcante et al., 2010; Nazário et al., 2010).

There are several alternatives to mitigate the effects of irrigation water salts on plants, e.g., the application of organic inputs in the soil, such as the humus from vermicomposting, which is a low-cost technological system (Bassaco et al., 2015). This compound, in addition to generating a nutrient-rich material, easily assimilated by plants, contains organic material of high molecular weight such as fulvic acids, humic acids and humin (Fernandes et al., 2009; Yadav \& Garg, 2011).

Based on these considerations, this study aimed to evaluate the growth and chlorophyll index of noni in response to the salinity of irrigation water in substrates with and without vermicompost.

\section{Material ANd Methods}

The experiment was conducted from April 2015 to January 2016, in a greenhouse located at the Centro de Humanas, Sociais e Ciências Agrárias (CCHSA) of the Universidade Federal da Paraíba (UFPB) in the municipality of Bananeiras, PB, Brazil.

Bananeiras is located in the 'Agreste' Mesoregion and 'Brejo' Microregion of Paraíba State, at the geographic coordinates $6^{\circ} 46^{\prime} \mathrm{S}$ and $35^{\circ} 38^{\prime} \mathrm{W}$, at $552 \mathrm{~m}$ of altitude. The climate in the region is classified as As', which means hot and humid (Brasil, 1972). The rainy season occurs from April to August and the dry season from September to December. The accumulated rainfall during the experiment was $1,242 \mathrm{~mm}$ (AESA, 2017).
For the substrate preparation, the soil was collected at $20 \mathrm{~cm}$ depth in an Oxisol in the Agricultural Sector of the CCHSA/ UFPB. The earthworm humus was obtained from the seedbed vermicomposting, carried out in the seedling nursery of the institution. The organic residues used to feed the red californian earthworms (Eisenia foetida) were plant remains collected in the agricultural area of the abovementioned institution. The humus was obtained with 90 days. After being removed from the seedbed, the humus was dried in the shade.

The chemical characterization of soil and humus was performed according to EMBRAPA (2014) and the results obtained are shown in Table 1.

The treatments were distributed in a completely randomized design, with four repetitions using the $4 \times 3$ factorial design, corresponding to four levels of electrical conductivity of the irrigation water $\left(0.5,1.5,3.0\right.$ and $\left.4.5 \mathrm{dS} \mathrm{m}^{-1}\right)$, and three substrates (soil without humus, soil with 33.33 and with $66.66 \%$ of humus). One noni plant in a $5 \mathrm{~L}$ plastic pot represented each experimental unit, totalizing 48 pots distributed in rows of $1.0 \mathrm{~m}$ in line and $1.0 \mathrm{~m}$ between the plants.

The seeds were obtained from mature fruits in adult noni plants one year old in the experimental area of CCHSA/UFPB. The ripe fruits were collected and, their pulp was removed and then the seeds were washed in running water to remove the remaining pulp.

For breaking the dormancy of noni seeds (integument dormancy), the most effective method (Leite et al., 2012) was used, by immersion of noni seeds in water for $48 \mathrm{~h}$. After the immersion, the sowing was carried out in plastic pots. Three seeds were sown in each experimental unit (pot). The thinning was performed 90 days after germination, leaving one plant in each pot.

The electrical conductivities of irrigation water were obtained based on the empirical relation proposed by Richards (1980). The salt used was sodium chloride; it was dissolved in water and the electrical conductivity was subsequently measured using a portable conductivity meter.

The entire irrigation period was carried out with salinity, from germination to plant removal. During the first 60 days after sowing (DAS), irrigation was performed manually, based on the weighing process, providing every $24 \mathrm{~h}$ the volume of evapotranspired water in each treatment in order to raise soil moisture (Souto et al., 2013). After this period, irrigation was performed three times a week.

Plant evaluations were carried out 95 days after sowing. Plant height, corresponding to the distance between the collar and the insertion of the last pair of leaves in the plant, was measured using a millimeter ruler. Stem diameter was measured using a Digimess ${ }^{\circledR} 300$ digital Caliper, at $10 \mathrm{~cm}$ from the plant collar, where it was marked with a dot made with ink to avoid experimental error. The number of leaves was counted in each plant.

Table 1. Chemical characterization of soil and humus

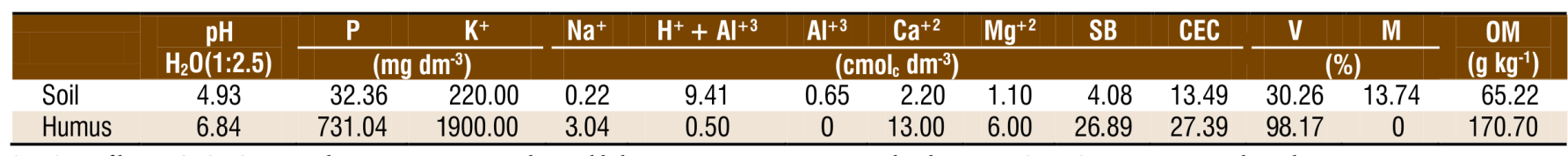

SB - Sum of bases, CEC - Cation exchange capacity, V - Exchangeable base saturation, M - saturation by aluminum, OM - Organic matter in the soil 
A portable chlorophyll meter (CFL1030 ClorofiLOG') was used to measure chlorophyll index in the central leaflet of the third expanded leaf of the plants, with two readings per leaf. From the readings, the device provided values proportional to the absorbance of chlorophylls $\mathrm{a}, \mathrm{b}$ and total $(\mathrm{a}+\mathrm{b})$ in dimensionless units called FCI values - Falker Chlorophyll Index (Falker Automação Agrícola Ltda, 2008).

After the end of the experiment, the fresh matter of shoots and roots was determined. Then, the plants were placed in an oven with air circulation at $65^{\circ} \mathrm{C}$ for $72 \mathrm{~h}$. After total drying, the dry matter of shoots and roots was evaluated.

The data were submitted to analysis of variance, and for the variables for which the interaction was not significant, the Tukey test was applied at $\mathrm{p} \leq 0.05$ for the substrates and the regression for the electrical conductivity of irrigation water. The Statistical Analysis System (SAS Institute, 2012) was used to process the data.

\section{Results AND Discussion}

From the summary of the analysis of variance, it was observed that plant height, fresh root biomass, dry root biomass and chlorophyll a were significantly influenced by the interaction between salinity and soil substrate. It is also verified that the stem diameter, number of leaves, fresh shoot biomass and total chlorophyll were influenced by electrical conductivity of the irrigation water and substrate (Table 2).

There was a quadratic effect on plant height with the increase of the electrical conductivity in the irrigation water in the substrate without humus. In the substrates with 33.33 and $66.66 \%$ of humus, there was a decreasing linear effect $(\mathrm{p} \leq 0.05)$ with increased salinity (Figure 1).

In the substrate without humus the plant growth was limited by the nutritional deficiency, as verified in the soil chemical analysis (Table 1), therefore the effect of salt stress was not the main limiting factor in plant height.

The addition of humus increased the absortion of nutrients by the plants in conditions of salinity; therefore, the growth in height was superior to that of plants not treated with humus.

In this way the humus solved the nutritional problem, due to the action of the humic matter in the improvement of the water storage capacity of the soil, besides providing nutrients (Fernandes et al., 2009).

The increase of salinity in irrigation water from 0.5 to $4.5 \mathrm{dS} \mathrm{m}^{-1}$ caused a decrease of 44.2 and $43.5 \%$ in the height of the plants of the treatments with 33.33 and $66.66 \%$ of humus, respectively, in comparison to the control.

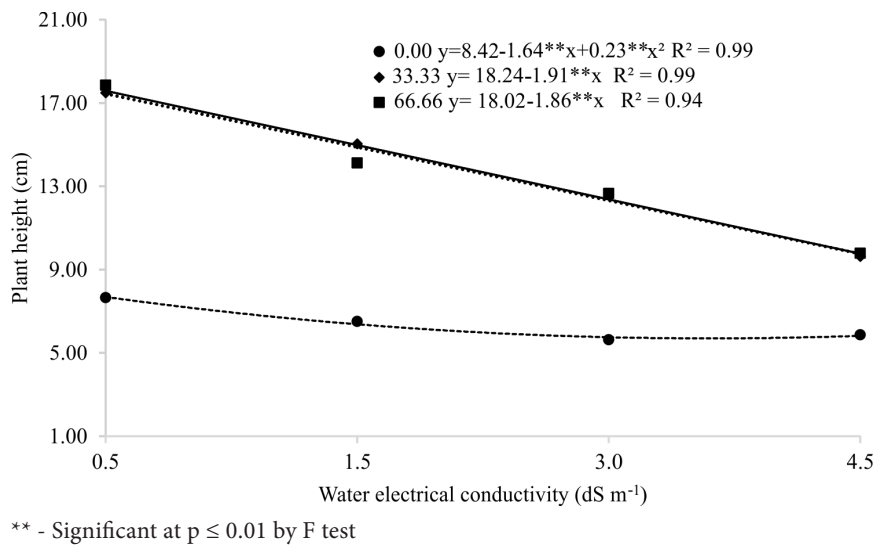

Figure 1. Height of noni plants as function of irrigation water electrical conductivity in three substrates

Salinity affects the ion activity in solution and in the processes of absorption, transport, assimilation and distribution of nutrients (Neves et al., 2009).

It was verified that with increasing electrical conductivity of the irrigation water there was a decreasing linear effect $(p \leq 0.05)$ in the treatment with $66.66 \%$ of humus and quadratic effect with addition of $33.33 \%$ of humus, for dry root biomass (Figure 2).

In the absence of humus, the root system of the plants was poorly developed compared to the substrate with the highest vermicompost addition, supposedly due to nutritional restriction. By comparing the results between the plants irrigated with water of highest and lowest electrical conductivity, losses of 26.88 and $80.24 \mathrm{~g}$ were observed for those maintained in the soil with 33.33 and $66.66 \%$ of humus, respectively.

Based on the results, the salt stress compromised the biomass production of the root system in response to the depressive effects of salinity. According to the level of salts, salinity can cause nutritional imbalance, loss of chlorophyll

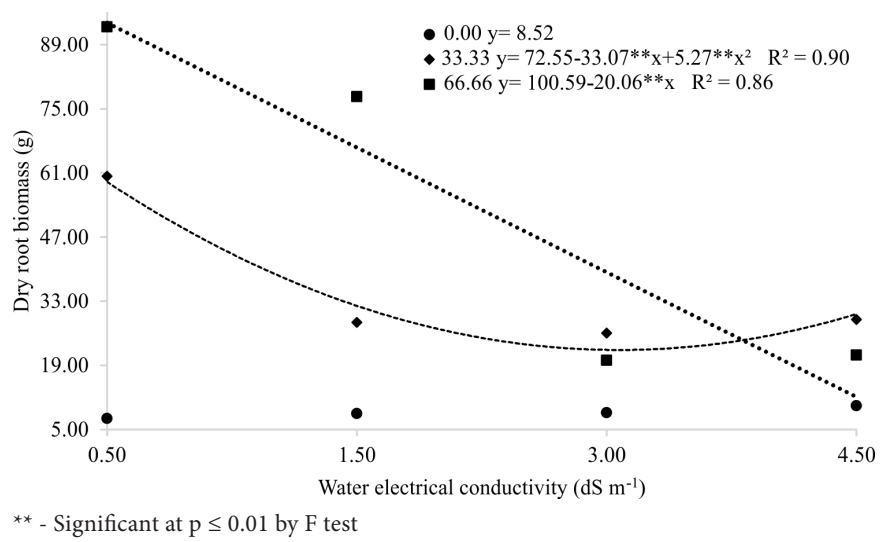

Figure 2. Dry root biomass of noni plants as function of irrigation water electrical conductivity in three substrates

Table 2. Summary of analysis of variance of the effect of irrigation water salinity (S) and substrate (SU) on the initial growth of the noni plant

\begin{tabular}{|c|c|c|c|c|c|c|c|c|c|c|c|}
\hline \multirow{2}{*}{ SV } & \multirow{2}{*}{ DF } & \multicolumn{10}{|c|}{ Mean square } \\
\hline & & $\overline{P H}$ & SD & LN & FSB & DSB & FRB & DRB & CA & CB & TC \\
\hline S & 3 & $51.11^{\star \star}$ & $6.80^{* *}$ & $6.30 * \star$ & $742.17^{*}$ & $36.14^{\mathrm{NS}}$ & $24662.08^{\star \star}$ & $2382.10^{\star \star}$ & $14.85^{\star \star}$ & $45.03^{\mathrm{NS}}$ & $73.90^{\star}$ \\
\hline SU & 2 & $196.77^{\star \star}$ & $41.47^{\star \star}$ & $12.07^{\star \star}$ & $26910.39 * \star$ & $1423.13^{\star \star}$ & $42297.92^{\star \star}$ & $5340.67^{\star \star}$ & 151.21 ** & 542.71 ** & $978.93^{\star \star}$ \\
\hline$S \times S U$ & 6 & 5.80 ** & $0.67^{\mathrm{NS}}$ & $0.64^{N S}$ & $306.98^{\mathrm{NS}}$ & $25.13^{\mathrm{NS}}$ & $7745.05^{\star \star}$ & $1228.67^{\star *}$ & $9.90 * *$ & $11.19^{N S}$ & $33.71^{\mathrm{NS}}$ \\
\hline Residual & 36 & 1.15569 & 0.3427 & 0.3051 & 206.3396 & 12.0400 & 1995.0694 & 207.5679 & 2.6965 & 23.2399 & 21.3804 \\
\hline CV (\%) & & 9.34 & 8.19 & 5.69 & 20.07 & 21.14 & 52.51 & 45.12 & 4.02 & 21.36 & 7.76 \\
\hline
\end{tabular}

PH - Plant height; SD - Stem diameter; LN - Leaf number; FSB - Fresh shoot biomass; DSB - Dry shoot biomass; FRB - Fresh root biomass; DRB - Dry root biomass; CA - Chlorophyll a; CB - Chlorophyll b; TC - Total chlorophyll; ${ }^{* *}$ - Significant effect at $\mathrm{p} \leq 0.01$; $^{*}$ - Significant effect at $\mathrm{p} \leq 0.05$; $^{\text {NS }}$ - Non-significant effect by the F test ( $\mathrm{p}>0.05$ ) 
and photosynthetic activity, reduction in the production of leaves, roots and leaf area (Souto et al., 2013, 2015b).

In addition, the negative effect of salinity on the dry matter of noni plants is attributed to the decrease in the osmotic potential of the soil solution which reduces the capacity of the plant to absorb water and nutrients, mainly due to the increase of the concentrations of soluble salts in the soil. Under these conditions, the plants diminish their vegetative growth and develop the root system to supply the need for nutrients and water (Asik et al., 2009; Alves et al., 2011).

It is observed in Figure 3 that there was a decreasing linear effect ( $p \leq 0.05)$ with the increase of the electrical conductivity in the irrigation water in the substrate without humus. With the addition of humus, the index of chlorophyll a increased, reaching the highest value (44.31 FCI) in the substrate with $66.66 \%$ humus and irrigated with $0.5 \mathrm{dS} \mathrm{m}^{-1}$.

The addition of vermicompost increased the presence of $\mathrm{N}(61.8 \%)$ and $\mathrm{Mg}(81.63 \%)$ in the substrate (Table 1). The higher availability of these elements has possibly increased the photosynthetic efficiency of the plants, and consequently the chlorophyll a index, as can be observed in the substrates with humus addition.

With an increase in the electrical conductivity, without humus, lower values of chlorophyll a index were observed. High levels of salts absorbed by plants contribute to an increase in the activity of chlorophyllase, an enzyme that degrades chlorophyll (Lima et al., 2004) and inhibits the photosynthetic action of plants (Taiz \& Zeiger, 2013). The results of Souto et al. (2015b) show that salt stress reduces chlorophyll index.

There was no statistical difference for stem diameter and number of leaves with the use of 33.33 and $66.66 \%$ of humus in the substrate. For all others variables a positive effect was observed for the vermicompost in the proportion of $66.66 \%$ (Table 3 ).

The plants showed better vegetative performance in the presence of humus in comparison to the control, proving a nutritional deficiency in the soil. Humus is a source of essential nutrients for the development of plants, containing phosphorus, sulfur, nitrogen and also some micronutrients (Góes et al., 2011).

The humus contributes to the increase of the cation exchange capacity of the soil, improving its physical and chemical properties (Góes et al., 2011). In addition, it decreases the depressive effects of salinity of irrigation water, not severely compromising the growth and biomass production of noni plants, as observed in this study.

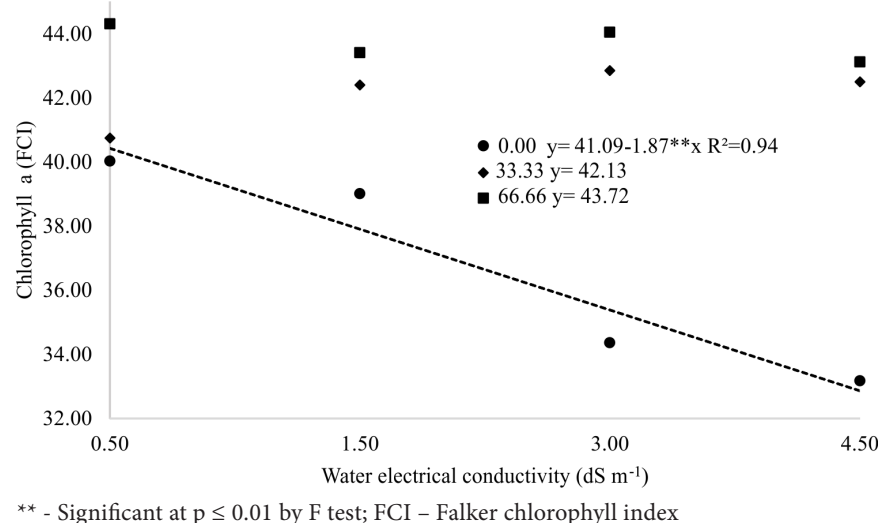

Figure 3. Leaf chlorophyll a in noni plants as function of irrigation water electrical conductivity in three substrates
Table 3. Effect of substrates with different humus concentrations on plant stem diameter (SD), leaf number (LN), fresh shoot biomass (FSB), dry shoot biomass (DSB), chlorophyll b (CB) and total chlorophyll (TC)

\begin{tabular}{lrcr}
\hline & \multicolumn{3}{c|}{ Humus $(\%)$} \\
\cline { 2 - 4 } Variables & $\mathbf{0}$ & $\mathbf{3 3 . 3 3}$ & $\mathbf{6 6 . 6 6}$ \\
\hline SD $(\mathrm{cm})$ & $4.84 \mathrm{~b}$ & $8.30 \mathrm{a}$ & $7.90 \mathrm{a}$ \\
LN & $8.67 \mathrm{~b}$ & $9.77 \mathrm{a}$ & $10.66 \mathrm{a}$ \\
FSB $(\mathrm{g})$ & $14.57 \mathrm{c}$ & $84.92 \mathrm{~b}$ & $110.40 \mathrm{a}$ \\
DSB $(\mathrm{g})$ & $4.07 \mathrm{c}$ & $18.24 \mathrm{~b}$ & $26.25 \mathrm{a}$ \\
CB (FCl) & $14.87 \mathrm{c}$ & $23.12 \mathrm{~b}$ & $29.51 \mathrm{a}$ \\
TC (FCl) & $48.48 \mathrm{c}$ & $61.84 \mathrm{~b}$ & $67.61 \mathrm{a}$ \\
\hline
\end{tabular}

Means followed by the same letter do not differ by the Tukey test at $\mathrm{p} \leq 0.05$; FCI - Falker chlorophyll index

\section{Conclusions}

1. The increase of salinity in irrigation water decreases growth and chlorophyll a and total chlorophyll indexes, but with lower intensity in substrates with humus.

2. Humus improves the fertility of the substrate and favors the growth of noni plants, regardless of the salinity of the irrigation water. However, the beneficial effect decreases with the intensification of salt stress.

\section{Literature Cited}

AESA - Agência Executiva de Gestão das Águas do Estado da Paraíba. Available on: <http://www.aesa.pb.gov.br/aesa-website/ meteorologia-chuvas>. Accessed on: Aug. 2017.

Alves, F. A. L.; Silva, S. L. F.; Silveira, J. A. G. da; Pereira, V. L. A. Efeito do $\mathrm{Ca}^{2+}$ externo no conteúdo de $\mathrm{Na}^{+}$e $\mathrm{K}^{+}$em cajueiros expostos a salinidade. Revista Brasileira de Ciências Agrárias, v.6, p.602-608, 2011. https://doi.org/10.5039/agraria.v6i4a1257

Amorim, A. V.; Gomes Filho, E.; Bezerra, M. A.; Prisco, J. T.; Lacerda, C. F. de. Respostas fisiológicas de plantas adultas de cajueiro anão precoce à salinidade. Revista Ciência Agronômica, v.41, p.113-121, 2010.

Asik, B. B.; Turan, M. A.; Celik, H.; Katkat, A. V. Effects of humic substances on plant growth and mineral nutrients uptake of wheat (Triticum durum cv. Salihli) under conditions of salinity. Asian Journal of Crop Science, v.1, p.87-95, 2009. https://doi. org/10.3923/ajcs.2009.87.95

Basar, S.; Uhlenhut, K.; Högger, P.; Schöne, F.; Westendoef, J. Analgesic and antiinflammatory activity of Morinda citrifolia L. (Noni) fruit. Phytother Research, v.24, p.38-42, 2010. https://doi.org/10.1002/ ptr.2863

Bassaco, A. C.; Antoniolli, Z. I.; Brum Júnior, B. de S.; Eckhardt, D. P.; Montagner, D. F.; Bassaco, G. P. Caracterização química de resíduos de origem animal e comportamento de Eisenia andrei. Ciência e Natura, v.37, p.45-51, 2015. https://doi. org/10.5902/2179460X13241

Brasil. Levantamento exploratório e conhecimento de solos do estado da Paraíba. Rio de Janeiro: Ministério da Agricultura, Pecuária e Abastecimento, 1972. 670p. Boletim Técnico, 15

Cavalcante, L. F.; Vieira, M. da S.; Santos, A. F. dos; Oliveira, W. M. de; Nascimento, J. A. M. do. Água salina e esterco bovino liquido na formação de mudas de goiabeira cultivar Paluma. Revista Brasileira de Fruticultura, v.32, p.251-261, 2010. https://doi. org/10.1590/S0100-29452010005000037 
EMBRAPA - Empresa Brasileira de Pesquisa Agropecuária. Sistema brasileiro de classificação de solos. 4.ed. Brasília: Embrapa Informação Tecnológica, 2014. 266p.

Falker Automação Agrícola Ltda. Manual do medidor eletrônico de teor clorofila (ClorofiLOG / CFL 1030). Porto Alegre: Falker Automação Agrícola Ltda, 2008. 33p.

Fernandes, J. D.; Monteiro Filho, A.; Santos, S. A. dos; Vasconcellos, A.; Santos, J. L. dos; Augusto, T. Utilização de diferentes substratos como iscas na captura de minhocas. Revista Brasileira de Agroecologia, v.4, p.2388-2391, 2009.

Goés, G. B. de; Dantas, D. J.; Araújo, W. B. M. de; Melo, I. G. C. e; Mendonça, V. Utilização de húmus de minhoca como substrato na produção de mudas de tamarindeiro. Revista Verde de Agroecologia e Desenvolvimento Sustentável, v.6, p.125-131, 2011.

Leite, G. A.; Cunha, P. S. de C. F.; Mendonça, L. F. de M.; Medeiros, P. V. Q. de; Mendonça, V. Superação de dormência de sementes de noni. Revista Verde de Agroecologia e Desenvolvimento Sustentável, v.7, p.120-128, 2012.

Lima, M. da G. de S.; Lopes, N. F.; Bacarin, M. A.; Mendes, C. R. Efeito do estresse salino sobre a concentração de pigmentos e prolina em folhas de arroz. Bragantia, v.63, p.335-340, 2004. https://doi. org/10.1590/S0006-87052004000300003

Nazário, A. A.; Garcia, G. de O.; Gonçalves, I. Z.; Madalão, J. C.; Araujo, G. L. Crescimento do cafeeiro conilon irrigado com água salina. Engenharia Ambiental, v.7, p.178-195, 2010.

Neves, A. L. R.; Lacerda, C. F. de; Guimarães, F. V. A.; Hernandez, F. F. F.; Silva, F. B. da; Prisco, J. T.; Gheyi, H. R. Acumulação de biomassa e extração de nutrientes por plantas de feijãode-corda irrigadas com água salina em diferentes estádios de desenvolvimento. Ciência Rural, v.39, p.758-765, 2009. https:// doi.org/10.1590/S0103-84782009005000014

Razafimandimbison, S. G.; McDowell, T. D.; Halford, D. A.; Bremer, B. Origin of the pantropical and nutriceutical Morinda citrifolia L. (Rubiaceae): Comments on its distribution range and circumscription. Journal of Biogeography, v.37, p.520-529, 2010. https://doi.org/10.1111/j.1365-2699.2009.02229.x
Richards, L. A. Suelos salinos y sodicos. Ciudad de México: Instituto Nacional de Investigaciones Agrícolas, 1980. 171p.

SAS Institute - Statistical Analysis System. SAS/STAT: User's guide statistics. Cary: SAS Institute, 2012.

Silva, J. J. M.; Cavalcante, L. F. Noni: Breve conhecimento da planta e bases para a produção. João Pessoa: Sal da Terra, 2014. 131p.

Silva, J. J. M.; Cavalcante, L. F.; Nascimento, J. A. M.; Diniz, B. L. M. T.; Souto, A. G. L. Esterco bovino e potássico na composição mineral de plantas de noni. Ciência Florestal, v.24, p.1021-1030, 2014. https://doi.org/10.5902/1980509816615

Souto, A. G. de L.; Cavalcante, L. F.; Diniz, B. L. M. T.; Mesquita, F. O.; Nascimento, J. A. M.; Lima Neto, A. J. Água salina e biofertilizante bovino na produção de frutos e alocação de biomassa em noni (Morinda citrifolia L.). Revista Brasileira de Plantas Medicinais, v.17, p.340-349, 2015a. https://doi.org/10.1590/1983-084X/13_039

Souto, A. G. de L.; Cavalcante, L. F.; Gheyi, H. R.; Nunes, J. C.; Oliveira, F. I. F.; Oresca, D. Photosynthetic pigments and biomass in noni irrigated with saline waters with and without leaching. Revista Brasileira de Engenharia Agrícola e Ambiental, v.19, p.1035-1041, 2015b. https://doi.org/10.1590/1807-1929/agriambi. v19n11p1035-1041

Souto, A. G. de L.; Cavalcante, L. F.; Lima Neto, A. de J.; Mesquita, F. de O.; Santos, J. B. dos. Biometria em plantas de noni sob irrigação com águas salinas e lixiviação dos sais do solo. Revista Ciência Agronômica, v.47, p.316-324, 2016.

Souto, A. G. de L.; Cavalcante, L. F.; Nascimento, J. A. M. do; Mesquita, F. de O.; Lima Neto, A. de J. Comportamento do noni à salinidade da água de irrigação em solo com biofertilizante bovino. Irriga, v.18, p.442-453, 2013. https://doi.org/10.15809/ irriga.2013v18n3p442

Taiz, L.; Zeiger, E. Fisiologia vegetal. 5.ed. Porto Alegre: Artmed, 2013. 954p.

Yadav, A.; Garg, V. K. Vermicomposting: An effective tool for the management of invasive weed Parthenium hysterophorus. Bioresource Technology, v.102, p.5891-5895, 2011. https://doi. org/10.1016/j.biortech.2011.02.062 